\title{
THE DESIGN OF ECONOMIC MICRO-IRRIGATION LATERALS BY COMPUTER AID
}

\author{
Abd El-Mageed, H. N. ${ }^{1}$, M. M. Ibrahim ${ }^{2}$, O. M. Elsherbiny ${ }^{3}$
}

\begin{abstract}
To design micro-irrigation laterals, by an accurate, simple and quick method, The OPT-LAT model was created. The model calculates the maximum lateral length with field length in $x$-axis or $y$-axis at different lateral diameters. It can also estimate the optimal diameter that meets least cost irrigation system. Not only that, but also it can compare between optimal lateral diameter in $x$-axis or $y$-axis. The validity of OPTLAT model was proved through the comparison between the lateral lengths calculated by the model and the corresponding ones calculated by Osama (2). The model has been applied on $160 \mathrm{~m} \times 120 \mathrm{~m}$ plot area as a case study. At the $x$-axis direction, the lateral lengths were $58 \mathrm{~m}$ for different lateral diameters, the optimal internal diameter was $13.6 \mathrm{~mm}$ at annual least cost of 0.229 L.E/m/year and less percent of pressure head variation of $12 \%$ at lateral diameter of $36 \mathrm{~mm}$. The corresponding values at y-axis were $78 \mathrm{~m}$ lateral lengths, the optimal internal diameter was $13.6 \mathrm{~mm}$ at annual least cost of $0.239 \mathrm{~L} . \mathrm{E} / \mathrm{m} /$ year and less percent of pressure head variation of $12.04 \%$ at lateral diameter of $36 \mathrm{~mm}$. These results indicate that as the diameters of the laterals increased, the percent of the pressure head variation decreased, annual fixed cost increased and repair plus energy annual costs increased. The above results depend on energy price and pipe price according to its material type.
\end{abstract}

Keywords: Computer model, Micro-irrigation lateral, Annual cost, Optimal diameter, Lateral length.

\footnotetext{
${ }^{1}$ Prof. of Agric. Eng., Faculty of Agric., Al-Mansoura Univ.

${ }^{2}$ Assoc. Prof. of Agric. Eng., Faculty of Agric., Al-Mansoura Univ.

${ }^{3}$ Demonstrator, Agric. Eng. Dept., Faculty of Agric., Al-Mansoura Univ.
} 


\section{INTRODUCTION}

$\mathrm{M}$

icro-irrigation is one of the latest advances for applying water and it represents a definite progression in irrigation technology. The main problem in irrigation network planning is that there are no hard-fast scientific rules to depend on. Therefore, planning varies from one designer to another (Ahmed, 1997). A major challenge in system design is to select the optimum size and number of subunits that will achieve economical and efficient operation (Keller and Karmeli, 1975). Designing trickle irrigation systems is intensive in numerical calculations. The use of computers removes much of tedious work associated with repetitive complex calculations and the manipulation of large pools of data. This, results in less error frequency and more detailed analysis when compared to noncomputer aided design (Zazueta et al., 1985). The most important advantages of the computer modeling, is the ability of analyzing interlaced or overlapping variables. In other words, if the change of one or more of the independent variables causes changing in other independent variables, and so on, this system, hence, is a complex system. Only computer modeling can trace these hundreds of operation and calculations till iteration steps in a specific condition. However, computer modeling is ideal for irrigation system analysis and design. The computer-aided design is necessary for accurate and quick design. So, bearing in mind the large number of alternatives under evaluation to select the optimal design, and the hardness of assessing each alternative. Hence, computer modeling must be used in this engineering process (El-Nesr, 1999). Few studies have reported the economic pipe size design. A computer model was used to assist the user in selecting the most economical (minimum total capital plus operational costs) design for trickle irrigation submain unit (Sharaf, 1996). A computer model called OSAMA (2) which calculates the maximum lengths of lateral and manifold according to the following limitation: (1) Water velocity in the lateral and the manifold should not exceed, 1.0 and 1.5 $\mathrm{m} / \mathrm{sec}$ respectively, (2) Friction losses in the lateral and manifold should not exceed $55 \%$ and $45 \%$ of the total allowable losses, respectively, (3) Flow rate in the inlet of the unit should not exceed 12.5 and $25 \mathrm{~m}^{3} / \mathrm{h}$ 
for single and double lateral unit, respectively. Program outputs were the maximum lateral length and dripper discharge at different flow variations (Suliman et al., 2004). Few studies have reported the performance characteristics of each emitter type. A computer model was developed for relating irrigation water temperatures to emitter discharge rate. According to this study, one may conclude that the pressure of the irrigation system is the dominant factor in the emitter discharge variation. Comes in descending order the emitter type, then the variation in irrigation water temperature (Ramadan et al., 2003). The manufacturing variation coefficient, emitter discharge coefficient and emitter discharge exponent were calculated due to establish flow sensitivity to pressure and compare manufacturers' specifications (Hezarjaribi et al., 2008). The results indicated that for the chosen emitters the manufacturers supplied data are not reliable for design purposes. Reliable, field tests are required prior to the design of a drip system. In fact, using the manufacturer's data will lead to nonuniformity of discharge throughout the system.

The main objectives of this study were to create a model able to estimate the most economic lateral design with respect to their number, maximum length and internal diameter in both directions.

\section{METHODOLOGY}

A model named OPT-LAT was created using Oracle Developer Suite $10 \mathrm{~g}$ (forms) and Oracle Database 10g (PL/SQL Language) to achieve the main objectives of this study. OPT-LAT model database stored with information about the available diameter of Polyethylene pipe (PE) and number of brake horsepower hours per unit of fuel Table (1). The stored data can be inserted and edited or deleted at any time. OPT-LAT model was fed by emitter characteristics, type of connections, distance between emitters $\left(\mathrm{S}_{\mathrm{e}}\right)$, design emission uniformity $(\mathrm{EU})$, field length in $\mathrm{x}$-axis $\left(\mathrm{L}_{\mathrm{X}}\right)$, field length in $\mathrm{y}$-axis $\left(\mathrm{L}_{\mathrm{Y}}\right)$ and input data for economical calculations. OPT-LAT model outputs were the maximum lateral length in $\mathrm{x}$-axis $\left(\mathrm{L}_{\mathrm{LX}}\right)$ or $\mathrm{y}$-axis $\left(\mathrm{L}_{\mathrm{LY}}\right)$ at different lateral diameters $\left(\mathrm{D}_{\mathrm{i}}\right)$, number of lateral on both sides of manifold $\left(\mathrm{N}_{\mathrm{Lx}}\right)$ or $\left(\mathrm{N}_{\mathrm{Ly}}\right)$, percent of pressure head variation $\left(\mathrm{H}_{\mathrm{var}}\right)$ and annual cost $\left(\mathrm{TC}_{\mathrm{p}}\right)$. 
Table (1): Typical number of brake horse power hours per unit fuel according to (USDA, 2013)

\begin{tabular}{c|c}
\hline Fuel Type & Expected Brake Horsepower-hours \\
\hline Diesel & $4.0 \mathrm{hp} . \mathrm{hr} / \mathrm{liter}$ \\
Natural gas & $3.0 \mathrm{hp} . \mathrm{hr} / \mathrm{m}^{3}$ \\
Electric & $1.2 \mathrm{hp} . \mathrm{hr} / \mathrm{KWh}$ at meter \\
\hline
\end{tabular}

The following steps were used to calculate the most economic pipe diameter for lateral:

\section{The maximum allowable friction losses in the lateral $\left(\Delta H_{1}\right)$ :}

To calculate the maximum allowable friction losses in the lateral, the sequence of steps have been followed:

Firstly, emitter flow rates are characterized by empirically determining flow rates as a function of operating pressure. The flow and hydraulic pressure relations are given by (Pitts et al., 1986) as follows.

$$
\mathrm{q}_{\mathrm{av}}=\mathrm{k}_{\mathrm{d}} \cdot \mathrm{h}_{\mathrm{av}}{ }^{\mathrm{x}}
$$

Where:

$\mathrm{h}_{\mathrm{av}}=$ The emitter operating pressure head, (m).

$\mathrm{q}_{\mathrm{av}}=$ The emitter discharge, $(\mathrm{L} / \mathrm{hr})$.

$\mathrm{K}_{\mathrm{d}}=$ The emitter discharge coefficient.

$\mathrm{x}=$ The emitter flow exponent.

Secondly, it can calculate minimum allowable emitter flow $\left(h_{n}\right)$ according to (ASAE, 1990) who suggests the following equation (2) to estimate design emission uniformity in terms of $\mathrm{C}_{\mathrm{v}}$ and pressure variation at the emitter, as well (Karmeli and Keller, 1974) cited by (Burt et al., 1997).

$$
\begin{gathered}
\mathrm{EU}=100\left[1-\frac{1.27 C_{v}}{\sqrt{\mathrm{N}_{\mathrm{e}}}}\right]\left(\frac{\mathrm{q}_{\mathrm{n}}}{\mathrm{q}_{\mathrm{av}}}\right) \\
\mathrm{q}_{\mathrm{n}}=\frac{\mathrm{EU} \times \mathrm{q}_{\mathrm{av}}}{100\left[1-\frac{1.27 \mathrm{C}_{\mathrm{v}}}{\sqrt{\mathrm{N}_{\mathrm{e}}}}\right]} \\
\frac{\mathrm{q}_{\mathrm{av}}}{\mathrm{q}_{\mathrm{n}}}=\left(\frac{\mathrm{h}_{\mathrm{av}}}{\mathrm{h}_{\mathrm{n}}}\right)^{\mathrm{X}}
\end{gathered}
$$

Where:

$$
\mathrm{q}_{\mathrm{n}}=\text { The minimum emitter discharge in the subunit, (L/hr). }
$$


$\mathrm{h}_{\mathrm{n}}=$ The minimum emitter operating pressure head in the subunit, (m).

$\mathrm{EU}=$ The design emission uniformity, $(\%)$.

$\mathrm{C}_{\mathrm{v}}=$ The manufacturer's coefficient of variation.

$\mathrm{N}_{\mathrm{e}}=$ The number of emitters per plant.

Thirdly, it can calculate the allowable pressure variation in the subunit $\left(\Delta \mathrm{H}_{\mathrm{s}}\right)$ that gives an EU reasonably close to the desired design value as to (Keller and Bliesner, 1990). $\Delta \mathrm{H}_{\mathrm{s}}$ is calculated according to the following equation:

$$
\Delta \mathrm{H}_{\mathrm{s}}=2.5 \times\left[\mathrm{h}_{\mathrm{av}}-\mathrm{h}_{\mathrm{n}}\right]
$$

Where:

$\Delta \mathrm{H}_{\mathrm{s}}=$ The allowable subunit pressure head variation, (m).

Finally, the allowable friction losses in the lateral $\left(\Delta \mathrm{H}_{1}\right)$ and manifold $\left(\Delta \mathrm{H}_{\mathrm{m}}\right)$ should not exceed $55 \%$ and $45 \%$ of the allowable pressure variation in the subunit, respectively according to (Karmeli and Keller, 1975).

\section{Maximum lateral length for both axes $\left(L_{L x}, L_{L Y}\right)$ :}

The program assumed that the number of laterals in both sides would be changed in ascending order starting from one until the total friction losses less or equal to the allowable friction losses $\left(\mathrm{N}_{\mathrm{lx}}\right.$ or $\mathrm{N}_{\mathrm{ly}}=1,2,4,6,8$, etc.). The length of one side lateral for both axes could be calculated as follows:

$$
\begin{aligned}
& L_{L X}=\frac{L_{X}-s_{p}-\left(N_{L X}-1\right) \cdot s_{p}}{2 \times N_{L x}} \\
& L_{L Y}=\frac{L_{Y}-s_{p}-\left(N_{L Y}-1\right) \cdot s_{p}}{2 \times N_{L Y}}
\end{aligned}
$$

Where:

$\mathrm{L}_{\mathrm{LX}}=$ The length of on one side lateral in $\mathrm{x}$-axis, (m).

$\mathrm{L}_{\mathrm{LY}}=$ The length of on one side lateral in y-axis, (m).

$\mathrm{L}_{\mathrm{X}}=$ The field length in $\mathrm{X}$-direction, $(\mathrm{m})$.

$\mathrm{L}_{\mathrm{Y}}=$ The field length in y-direction, $(\mathrm{m})$.

$\mathrm{N}_{\mathrm{LX}}=$ The number of lateral along both sides manifold in $\mathrm{x}$-axis.

$\mathrm{N}_{\mathrm{LY}}=$ The number of lateral along both sides manifold in y-axis. 


\section{Total friction losses in the lateral $\left(\mathrm{H}_{\mathrm{fL}}\right)$ :}

The following steps were used for calculating total friction losses:

a) The total number of emitters on lateral can be estimated as follows:

$$
\begin{aligned}
& N_{e}=\frac{L_{L X}}{s_{e}} \\
& N_{e}=\frac{L_{L Y}}{s_{e}}
\end{aligned}
$$

Where:

$\mathrm{N}_{\mathrm{e}}=$ The total number of emitters along one side lateral.

$\mathrm{s}_{\mathrm{e}}=$ The distance between emitters, $(\mathrm{m})$.

b) The total discharge of one side lateral was calculated according the following equation:

Where:

$$
\mathrm{q}_{\mathrm{L}}=\mathrm{N}_{\mathrm{e}} \cdot \mathrm{q}_{\mathrm{av}}
$$

$\mathrm{q}_{\mathrm{L}}=$ The total discharge of one side lateral, $(\mathrm{L} / \mathrm{hr})$.

c) The connection losses were calculated for on-line connection (sizes, large, medium and small connections), also for in-line connection. The equivalent length $\left(\mathrm{f}_{\mathrm{e}}\right)$ is given by (Montalvo, 1983) and (SCS, 1984). The value of $f_{e}$ is assumed as 0.23 for in-line connection and the $f_{e}$ is calculated for on-line connection sizes according to the following equation:

$$
\begin{gathered}
\mathrm{f}_{\mathrm{e}}=\frac{23.04}{\mathrm{D}_{\mathrm{i}}^{1.84}} \quad \text { Large Connection }\left(\mathrm{D}_{\mathrm{e}}=7.5 \mathrm{~mm}\right) \\
\mathrm{f}_{\mathrm{e}}=\frac{18.91}{\mathrm{D}_{\mathrm{i}}^{1.87}} \quad \text { Standard connection }\left(\mathrm{D}_{\mathrm{e}}=5 \mathrm{~mm}\right) \\
\mathrm{f}_{\mathrm{e}}=\frac{14.38}{\mathrm{D}_{\mathrm{i}}^{1.89}} \quad \text { Small connection }\left(\mathrm{D}_{\mathrm{e}}=3.8 \mathrm{~mm}\right) \ldots
\end{gathered}
$$

Where:

$\mathrm{f}_{\mathrm{e}}=$ The equivalent length, $(\mathrm{m})$.

$\mathrm{D}_{\mathrm{i}}=$ The internal lateral diameter, $(\mathrm{mm})$.

$\mathrm{D}_{\mathrm{e}}=$ The on-line emitter protrusion diameter, $(\mathrm{mm})$.

d) The friction head loss along the lateral line can be calculated by multiplying Eq. (15) by the Christiansen adjustment coefficient (F), according to (Christiansen, 1942). Reduction factor $(F)$ depends on 
the discharge exponent of friction loss formula and the number of outlets in the line. For multiple-outlet pipes, the total friction head loss is equal to the sum of the losses between the outlets. The following equation was used for calculating reduction factor:

$$
\mathrm{F}=\frac{1}{\mathrm{~m}+1}+\frac{1}{2 \mathrm{~N}_{\mathrm{e}}}+\frac{\sqrt{\mathrm{m}-1}}{6 \mathrm{~N}_{\mathrm{e}}^{2}}
$$

Where:

$\mathrm{F}=$ The christiansen adjustment coefficient (reduction factor).

$\mathrm{m}=$ The discharge exponent of friction loss formula $=1.852$ for turbulent flow using the Hazen-Williams equation according to (Wu et al., 1986).

Total friction losses in the lateral $\left(\mathrm{H}_{\mathrm{fL}}\right)$ are determined using the HazenWilliams equation:

$$
\mathrm{H}_{\mathrm{fL}}=\frac{\mathrm{K} \times \mathrm{L}_{\mathrm{L}}}{\mathrm{D}_{\mathrm{i}}^{4.87}} \times\left(\frac{\mathrm{q}_{\mathrm{L}}}{\mathrm{C}}\right)^{1.852} \times \mathrm{F} \times\left(\frac{\mathrm{S}_{\mathrm{e}}+\mathrm{f}_{\mathrm{e}}}{\mathrm{S}_{\mathrm{e}}}\right)
$$

Where:

$\mathrm{L}_{\mathrm{L}}=$ The length of one side lateral in $\mathrm{x}$-axis $\mathrm{L}_{\mathrm{Lx}}$ or in $\mathrm{y}$-axis $\mathrm{L}_{\mathrm{LY}},(\mathrm{m})$.

$\mathrm{D}_{\mathrm{i}}=$ The internal lateral diameter, $(\mathrm{mm})$.

$\mathrm{K}=$ The conversion constant, which is $1.212 \times 10^{10}$ for metric unit

$\mathrm{C}=$ The friction coefficient, which is a function of pipe material, characteristics Hazen-Williams roughness coefficient for $\mathrm{PE}=140$ according to (Keller and Bliesner, 1990).

The percent of pressure head variation $\left(\mathrm{H}_{\mathrm{var}}\right)$ :

For a fully laminar flow regime, emitters must be very sensitive to pressure head changes and the value of $x$ must be 1.0.This means that a pressure variation of $20 \%$ may result in $\pm 20 \%$ emitter flow rate variation. Most non-compensating emitters are always fully turbulent with an $x$ level of about 0.5 , indicating that a pressure variation of $20 \%$ will result in a flow variation of approximately $10 \%$ (Solomon and Bezdek 1980; Boswell, 1985). The following steps were estimated the percent of pressure head variation:

$$
\begin{aligned}
& \mathrm{h}_{\text {max }}=\mathrm{h}_{\mathrm{av}}+0.75 \mathrm{H}_{\mathrm{fL}} \\
& \mathrm{H}_{\mathrm{var}}=\frac{\mathrm{h}_{\max }-\mathrm{h}_{\mathrm{n}}}{\mathrm{h}_{\max }}
\end{aligned}
$$

Where: 
$\mathrm{H}_{\mathrm{var}}=$ The percent of pressure head variation, (\%).

$\mathrm{h}_{\text {max }}=$ The allowable maximum emitter operating pressure head, (m).

The OPT-LAT model can calculate the percent of pressure variation $\left(\mathrm{H}_{\mathrm{var}}\right)$ by gradually increasing to design emission uniformity (EU) when the percent of pressure variation was more than the percent of allowable emitter pressure variation.

\section{Estimating the most economically lateral diameter:}

The OPT-LAT model could be used to make comparison among different pipe diameters to estimate the most economically one. Input data for economic considerations were as follows: (1) pipe price according to its material type, (2) the number of years in the life cycle, (3) internal rate for capital, (4) type of engine used, (5) the equivalent annual rate of energy escalation, (6) brake horse power per unit of energy, (7) the annual numbers of hours to operate the pumps that was input data and (8) the following efficiencies were taken as $90 \%, 75 \%$ and $60 \%$ for electric engine, pump and internal combustion engine respectively. The sequence of steps to estimate the optimal lateral diameter have been followed:

1) The annual energy cost for lateral length can be estimated by using the following equation based on (SCS, 1984):

$$
\mathrm{EC}=\frac{(0.735) \times \mathrm{q}_{\mathrm{L}} \times \mathrm{H}_{\mathrm{fL}} \times \mathrm{T}_{\mathrm{si}} \times\left(\mathrm{C}_{\mathrm{e}} \times 1.36 / \mathrm{BHP}\right) \times \mathrm{Ca}}{75 \eta}
$$

Where:

$\mathrm{EC}=$ The annual energy cost of lateral, (L.E/year).

$\mathrm{C}_{\mathrm{e}}=$ The fuel cost: diesel, (L.E/L); natural gas (L.E $\left./ \mathrm{m}^{3}\right)$; electricity, (L.E / KW.hr).

$\eta=$ The overall pump efficiency, $(\%)$.

$\mathrm{T}_{\mathrm{si}}=$ The annual numbers of hours to operate the pumps, (hr).

$\mathrm{Ca}=$ The equivalent annualized escalating energy cost factor.

BHP = The typical number of brake horsepower hours per unit fuel.

The equivalent annualized escalating energy cost factor, $(\mathrm{Ca})$ is used to evaluate the effect of escalation on energy cost and can be calculated by (Jensen, 1981). 


$$
\mathrm{Ca}=\left[\frac{(1+\mathrm{e})^{\mathrm{N}}-(1+\mathrm{r})^{\mathrm{N}}}{(1+\mathrm{e})-(1+\mathrm{r})}\right]\left[\frac{\mathrm{r}}{(1+\mathrm{r})^{\mathrm{N}}-1}\right]
$$

Where:

$\mathrm{e}=$ The decimal equivalent annual rate of energy escalation, $(\%)$

$\mathrm{r}=$ The decimal equivalent annual interest rate, $(\%)$

$\mathrm{N}=$ The number of years in the life cycle, (Years)

2) The annual fixed cost for lateral length has been calculated as follows:

$$
\mathrm{FC}=\mathrm{C}_{\mathrm{p}} \times \mathrm{CR}
$$

Where:

$\mathrm{FC}=$ The annual fixed cost of calculated lateral length, (L.E/year).

$\mathrm{C}_{\mathrm{p}}=$ The pipe price that is a function of diameter and length, (L.E/m).

$\mathrm{CR}=$ The capital recovery factor can be calculated based on (James and Lee, 1971) as follows:

$$
\mathrm{CR}=\frac{\mathrm{r} \cdot(1+\mathrm{r})^{\mathrm{N}}}{(1+\mathrm{r})^{\mathrm{N}}-1}
$$

3) The annual maintenance cost (RC) varies from (1.5 to $2.5 \%)$ and (5 to $8 \%$ ) of the initial cost for $\mathrm{PE}$ pipe and emitters respectively, according to (Thompson et al., 1980).

4) Sum of the annual energy cost, the annual repair cost and the annual fixed cost of the pipe $\left(\mathrm{TC}_{\mathrm{p}}\right)$ were estimated as follows:

$$
\mathrm{TC}_{\mathrm{p}}=\mathrm{EC}+\mathrm{FC}+\mathrm{RC}
$$

Where:

$\mathrm{TC}_{\mathrm{p}}=$ The annual cost, (L.E/year).

$\mathrm{RC}=$ The annual maintenance cost of the PE pipe, (L.E/year).

5) Finally, it can estimate annual cost of lateral for different diameters, (L.E/m/year) then select the optimal diameter that gives the least cost of system design. 


\section{OPT-LAT flowchart:}

Steps for creating OPT-LAT are illustrated in Figure (1).

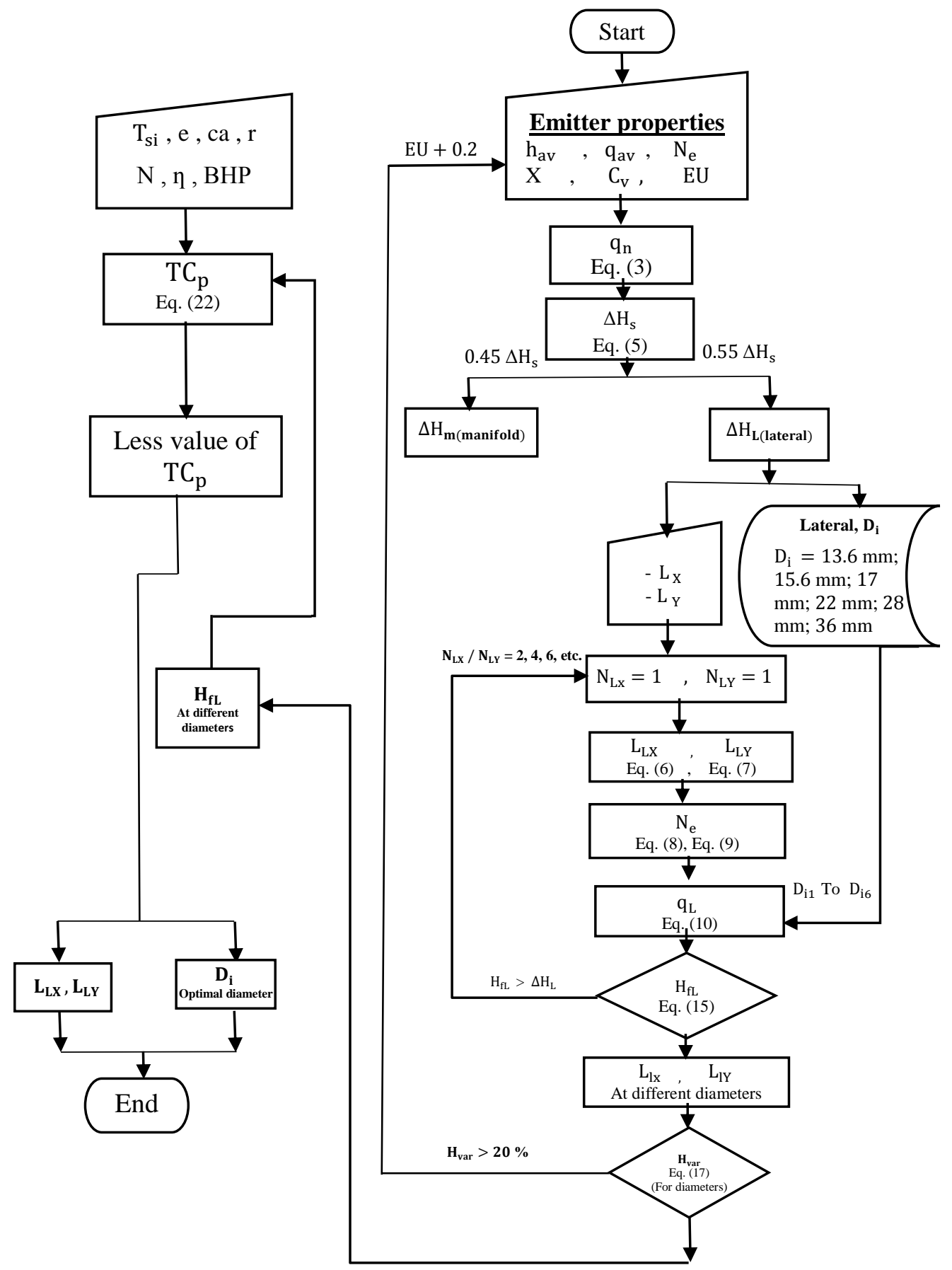

Figure (1): Flowchart describing the calculating economic pipe size for lateral. 


\section{RESULTS AND DISCUSSION}

\section{Model verification:}

The verification of the OPT-LAT model was tested through the comparison with Osama (2) program. Table (2) indicates the values of input data for Osama (2) model. These inputs were considered and fed to design a model OPT-LAT. The emitter characteristics were presented in Table (2): the discharge rate for emitters were 2, 3, 4, 6 and $8 \mathrm{~L} / \mathrm{h}$ and the connection type of emitters was on-line type. Other input, the flow variation was assumed $5 \%$ in this program. Internal lateral diameters of 13.6, 15.6 and $17 \mathrm{~mm}$ were stored in OPT-LAT model as a database. The design emission uniformity and emitter spacing were $91.5 \%$ and $0.5 \mathrm{~m}$ respectively. The output data of the two models were compared to the same entered input data as previously mentioned.

Table (2): Characteristics of the used emitters

\begin{tabular}{|c|c|c|c|c|c|}
\hline $\begin{array}{c}\mathbf{q}_{\mathrm{av}}, \\
(\mathbf{L} / \mathbf{h r})\end{array}$ & $\begin{array}{c}\mathbf{h}_{\mathbf{a v},} \\
(\mathbf{m})\end{array}$ & $\mathbf{K}_{\mathbf{d}}$ & $\mathbf{X}$ & $\mathbf{C V}$ & $\begin{array}{c}\mathbf{D}_{\mathbf{e}}, \\
(\mathbf{m m})\end{array}$ \\
\hline 2 & 10 & 0.6325 & 0.5 & 0.030 & 3.8 \\
\hline 3 & 11.763 & 0.6428 & 0.625 & 0.031 & 3.8 \\
\hline 4 & 10 & 1.2649 & 0.5 & 0.027 & 5.0 \\
\hline 6 & 11.073 & 2.3378 & 0.392 & 0.020 & 5.0 \\
\hline 8 & 10 & 2.5298 & 0.5 & 0.030 & 5.0 \\
\hline
\end{tabular}

$\mathrm{q}_{\mathrm{av}}, \mathrm{h}_{\mathrm{av}}, \mathrm{K}_{\mathrm{d}}, \mathrm{X}, \mathrm{CV}$ and $\mathrm{D}_{\mathrm{e}}$ are average emitter discharge (L/hr), emitter operating pressure head $(\mathrm{m})$, proportion factor, discharge exponent, manufacturer's coefficient of variation and emitter protrusion diameter respectively.

It could be noticed that lateral lengths obtained from OPT-LAT model were close to the corresponding ones resulted by Osama (2) according to Table (3). These results prove the validity of OPT-LAT model in calculating the maximum allowable lateral length.

The regression coefficient $\left(\mathrm{R}^{2}\right)$ between calculated lengths of laterals from OPT-LAT and Osama (2) at different emitter discharge rates of 2, 3, 4, 6 and $8 \mathrm{~L} / \mathrm{hr}$ are shown in Figure (2). The values of $\mathrm{R}^{2}$ were 0.9996, 0.9991 and 0.9996 for internal lateral diameters of 13.6, 15.6 and $17 \mathrm{~mm}$ respectively. These values shows that the OPT-LAT model can calculate accurately lateral length. 
Table (3): Lateral length at different emitter discharge rates and lateral diameters, $(\mathrm{m})$

\begin{tabular}{|c|c|c|}
\hline \multirow[b]{2}{*}{$\begin{array}{c}\mathrm{D}_{\mathbf{i}}, \\
(\mathrm{mm})\end{array}$} & \multicolumn{2}{|c|}{ Lateral lengths, (m) } \\
\hline & $\begin{array}{c}\text { Osama (2) } \\
\text { program output }\end{array}$ & $\begin{array}{l}\text { OPT-LAT Predicted } \\
\text { values }\end{array}$ \\
\hline \multicolumn{3}{|c|}{ Emitter discharge rate $=2 \mathrm{~L} / \mathrm{hr}$} \\
\hline 13.6 & 72.5 & 75.5 \\
\hline 15.6 & 92.5 & 95.5 \\
\hline 17 & 114.5 & 113 \\
\hline \multicolumn{3}{|c|}{ Emitter discharge rate $=3 \mathrm{~L} / \mathrm{hr}$} \\
\hline 13.6 & 54 & 56.5 \\
\hline 15.6 & 69 & 73 \\
\hline 17 & 85.5 & 85.5 \\
\hline \multicolumn{3}{|c|}{ Emitter discharge rate $=4 \mathrm{~L} / \mathrm{hr}$} \\
\hline 13.6 & 45 & 47.5 \\
\hline 15.6 & 58 & 60.5 \\
\hline 17 & 72 & 71 \\
\hline \multicolumn{3}{|c|}{ Emitter discharge rate $=6 \mathrm{~L} / \mathrm{hr}$} \\
\hline 13.6 & 39.5 & 41 \\
\hline 15.6 & 50.5 & 52.5 \\
\hline 17 & 63 & 62 \\
\hline \multicolumn{3}{|c|}{ Emitter discharge rate $=8 \mathrm{~L} / \mathrm{hr}$} \\
\hline 13.6 & 29 & 30 \\
\hline 15.6 & 37 & 39 \\
\hline 17 & 46 & 45 \\
\hline
\end{tabular}

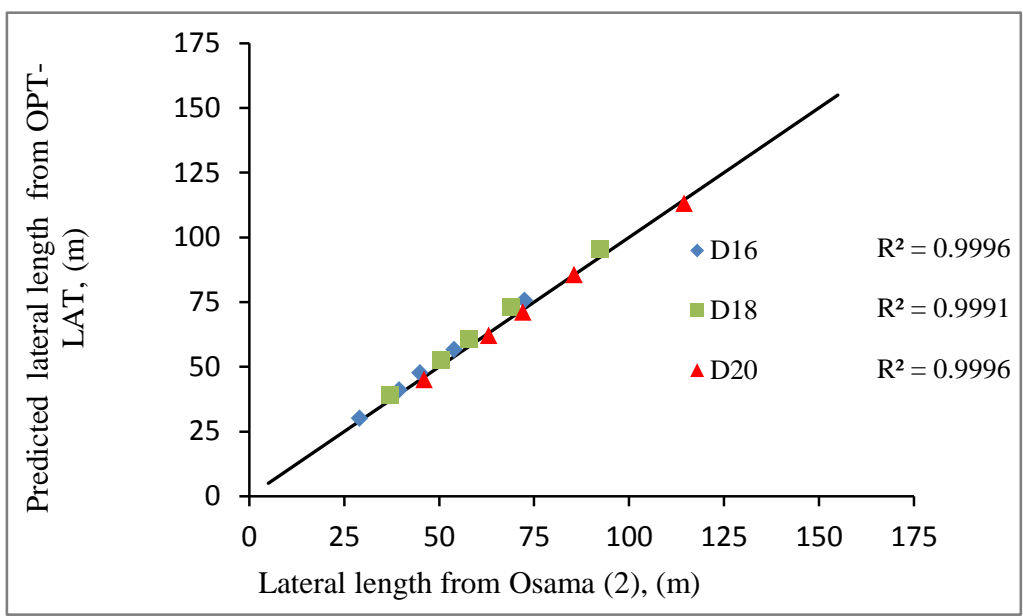

Figure (2): The correlation between lateral lengths from Osama (2) and predicted lateral lengths from OPT-LAT 


\section{Case study and analysis of the model results:}

To carry out the case study, the sequence of input operations has been followed: Firstly, emitter characteristics, plant data, design area and soil data were presented in Table (4). Secondly, lateral diameters of 13.6, 15.6, 17, 22, 28 and $36 \mathrm{~mm}$ are shown in Figure (3). Thirdly, price of P.E lateral of available diameters and the price of on-line emitter are exhibited in Figure (4). Finally, economic considerations to lateral design are shown in Table (5) and interface for input economic variables and select type of engine are shown in Figure (5). It could select type of power source to diesel, electric and natural gas engine. From OPT-LAT model output results, the following studies were carried out; the effect of lateral diameters on (1) total friction losses in the lateral (2) allowable pressure head variation (3) annual fixed cost, sum of energy plus repair annual costs, and annual cost.

Table (4): Input data for the case study

\begin{tabular}{|c|c|c|}
\hline \multicolumn{3}{|c|}{ Layout Parameters } \\
\hline \multicolumn{3}{|c|}{ Input } \\
\hline \multirow{4}{*}{ Plant } & Plant name & Grape \\
\hline & Tree spacing $(\mathrm{m} \times \mathrm{m})$ & $3 \times 3$ \\
\hline & Root depth (RZD), m & 1.2 \\
\hline & Average daily peak (ETc ), mm & 4.1 \\
\hline Climate & Moderate & \\
\hline \multirow{3}{*}{$\begin{array}{c}\text { Design } \\
\text { area }\end{array}$} & Field length in X-direction $\left(\mathrm{L}_{\mathrm{X}}\right), \mathrm{m}$ & 120 \\
\hline & Field length in Y-direction $\left(\mathrm{L}_{\mathrm{Y}}\right), \mathrm{m}$ & 160 \\
\hline & Field Total Area (A), Fed & 4.57 \\
\hline \multirow{3}{*}{ Soil } & Soil type & Clay \\
\hline & Hydraulic Conductivity coefficient (Ks), mm/hr & 5 \\
\hline & Water-holding capacity of the soil (WHC), $\mathrm{mm} / \mathrm{m}$ & 192 \\
\hline \multirow{7}{*}{ Emitter } & Average pressure head $\left(\mathrm{h}_{\mathrm{av}}\right), \mathrm{Kpa}$ & 103 \\
\hline & Average emitter discharge $\left(q_{\mathrm{av}}\right), \mathrm{L} / \mathrm{hr}$ & 4 \\
\hline & Discharge exponent $(\mathrm{X})$ & 0.45 \\
\hline & Discharge cofficient $\left(\mathrm{K}_{\mathrm{d}}\right)$ & 1.39 \\
\hline & Connection type & Standard \\
\hline & coefficient of variation in the manufacturing $(\mathrm{Cv}), \%$ & 3.5 \\
\hline & Emission Uniformity (EU), \% & 90 \\
\hline
\end{tabular}


Table (5): Input data for economic considerations

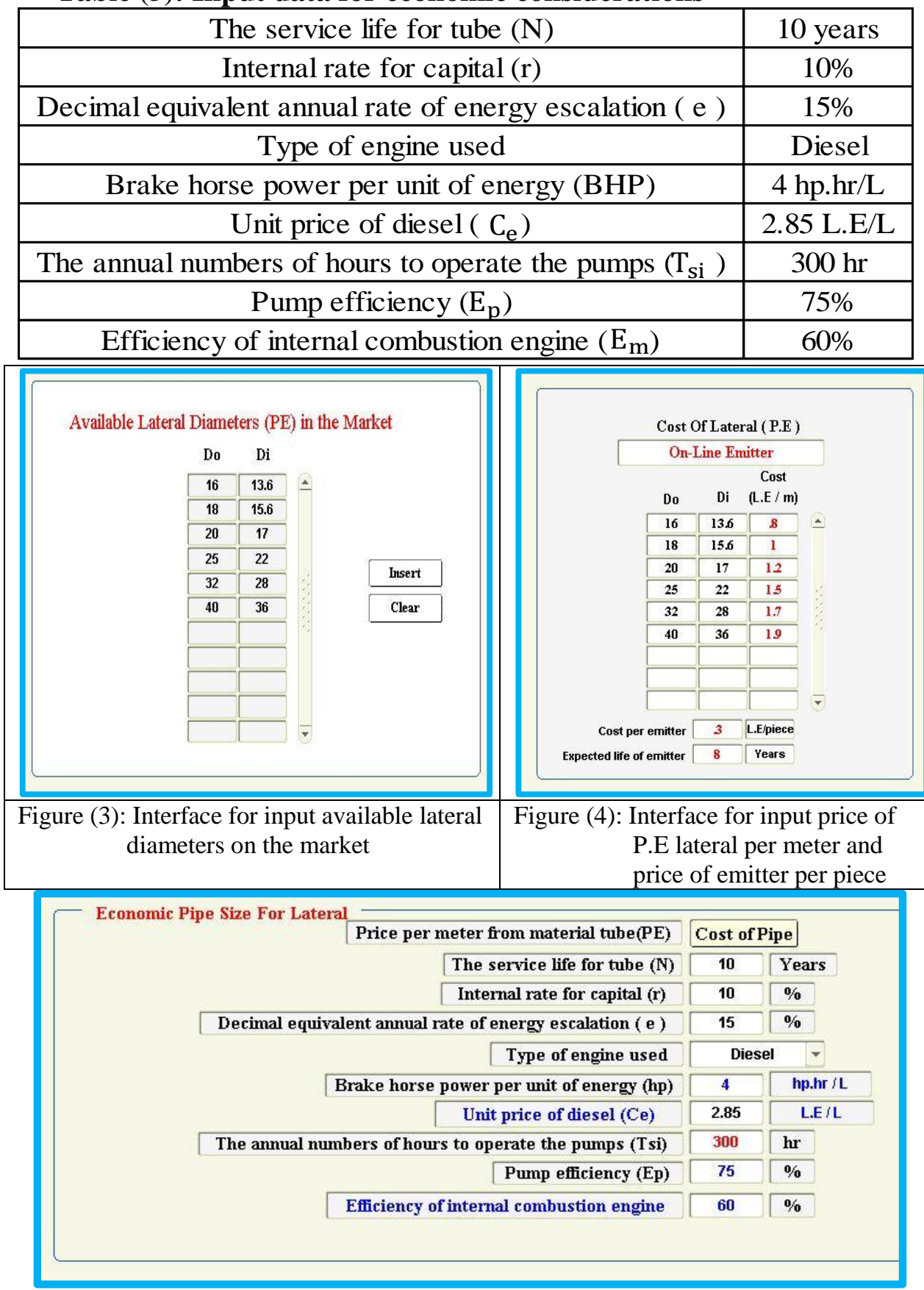

Figure (5): Interface for input economic variables and select type of engine

The main program interface for calculating the optimum lateral diameter is shown in Figure (6). The output of OPT-LAT model case study for 
design economic diameter of lateral were shown in Table (6) and in addition that, minimum operating pressure head in the subunit, distance between emitter, emission points per plant and design emission uniformity were $90.7 \mathrm{Kpa}, 1 \mathrm{~m}, 3$ and $92 \%$ respectively. The output data were as follows: maximum lateral lengths for both axes at different lateral diameters, number of laterals on both sides of the manifold at the two directions, percent of pressure head variation, annual fixed cost, repair plus energy annual costs and total annual cost of pipe.

\section{Table (6): Output data for selection of economic lateral diameter}

\begin{tabular}{|c|c|c|c|c|c|c|c|c|c|c|c|c|c|c|c|}
\hline \multicolumn{16}{|c|}{ Lateral in X-axis } \\
\hline $\begin{array}{l}\mathbf{L}_{\mathbf{x}} \\
(\mathbf{m})\end{array}$ & $\begin{array}{r}\mathrm{D}_{\mathrm{i}} \\
(\mathrm{mn}\end{array}$ & & $\mathbf{N}_{\mathbf{L}}$ & $\begin{array}{r}\mathbf{L}_{\mathbf{L}} \\
(\mathbf{m})\end{array}$ & $\begin{array}{c}\mathbf{q}_{\mathbf{L}} \\
(\mathrm{L} / \mathrm{hr})\end{array}$ & $\begin{array}{l}\mathbf{H}_{\mathrm{f} \mathrm{L}} \\
(\mathrm{m})\end{array}$ & & $\begin{array}{l}\Delta \mathbf{H}_{\mathrm{L}} \\
(\mathbf{m})\end{array}$ & $\begin{array}{l}H_{\text {var }} \\
(\%)\end{array}$ & (L.E & $\begin{array}{l}\text { FC } \\
/ \mathrm{m} / \text { Year })\end{array}$ & & $\begin{array}{l}\mathbf{R C}+\mathbf{E C} \\
\text { L.E } / \mathrm{m} / \text { Yea }\end{array}$ & $\begin{array}{l}\text { Car) } \\
\text { ear }\end{array}$ & $\begin{array}{c}\text { TC } \\
\text { (L.E/m/Year) }\end{array}$ \\
\hline \multirow{6}{*}{120} & 13. & & 1 & 58 & 231.94 & 0.575 & & \multirow{6}{*}{1.73} & 15.45 & & .1864 & & 0.0419 & & 0.229 \\
\hline & 15. & & 1 & 58 & 231.94 & 0.286 & & & 13.74 & & 0.219 & & 0.0432 & & 0.262 \\
\hline & 17 & & 1 & 58 & 231.94 & 0.185 & & & 13.12 & & .2515 & & 0.0459 & & 0.297 \\
\hline & 22 & & 1 & 58 & 231.94 & 0.051 & & & 12.29 & & .3004 & & 0.0502 & & 0.351 \\
\hline & 28 & & 1 & 58 & 231.94 & 0.015 & & & 12.07 & & .3329 & & 0.0537 & & 0.387 \\
\hline & 36 & & 1 & 58 & 231.94 & 0.004 & & & 12 & & .3654 & & 0.0576 & & 0.423 \\
\hline \multicolumn{16}{|c|}{ Lateral in $\mathrm{Y}$-axis } \\
\hline \multirow{6}{*}{160} & 13. & & 1 & 78 & 311.92 & 1.331 & \multirow{6}{*}{\multicolumn{2}{|c|}{1.73}} & 19.62 & & .1864 & & 0.0526 & & 0.239 \\
\hline & 15. & & 1 & 78 & 311.92 & 0.663 & & & 15.95 & & 0.219 & & 0.048 & & 0.267 \\
\hline & 17 & & 1 & 78 & 311.92 & 0.43 & & & 14.6 & & 0.2515 & & 0.049 & & 0.301 \\
\hline & 22 & & 1 & 78 & 311.92 & 0.118 & & & 12.71 & & 0.3004 & & 0.051 & & 0.351 \\
\hline & 28 & & 1 & 78 & 311.92 & 0.035 & & & 12.2 & & 0.3329 & & 0.054 & & 0.387 \\
\hline & 36 & & 1 & 78 & 311.92 & 0.010 & & & 12.04 & & 0.3654 & & 0.0576 & & 0.423 \\
\hline \multicolumn{12}{|c|}{ The optimum lateral diameter } & \multirow{2}{*}{\multicolumn{3}{|c|}{$\begin{array}{ccc}\text { F.C, } & \text { EC, } & \text { T. C, } \\
\text { LE' } & \text { Repair, } & \text { LEE } \\
\text { Year'm LEVear'm } & \text { Year'm }\end{array}$}} & \multirow{8}{*}{$\Delta$} \\
\hline & Do & Di & $\begin{array}{c}N \\
(L X / L Y\end{array}$ & L max & Ne (L) & $\begin{array}{c}q \\
(L / h r)\end{array}$ & $\mathrm{F}$ & $\mathrm{Fe}$ & Hfl, (m) & $\begin{array}{l}\text { Allow. } \\
\text { HL, (m) }\end{array}$ & $\begin{array}{c}\text { Var } \\
\text { H, (\%) }\end{array}$ & & & & \\
\hline$\sqsubset$ & 16 & 13.6 & 1 & 58 & 58 & 231.942 & .3593 & .1435 & .5755 & 1.728 & 15.45 & .1864 & .0429 & .229 & \\
\hline\ulcorner & 18 & 15.6 & 1 & 58 & 58 & 231.942 & .3593 & .1111 & .2867 & 1.728 & 13.74 & .219 & .0432 & .262 & \\
\hline$\square$ & 20 & 17 & 1 & 58 & 58 & 231.942 & .3593 & .0946 & .1858 & 1.728 & 13.12 & .2515 & .0459 & .297 & \\
\hline ᄃ & 25 & 22 & 1 & 58 & 58 & 231.942 & .3593 & .0584 & .0512 & 1.728 & 12.29 & .3004 & .0502 & .351 & \\
\hline ᄃ & 32 & 28 & 1 & 58 & 58 & 231.942 & .3593 & .0372 & .0155 & 1.728 & 12.07 & .3329 & .0537 & .387 & \\
\hline$\sqsubset$ & 40 & 36 & 1 & 58 & 58 & 231.942 & .3593 & .0232 & .0045 & 1.728 & 12 & .3654 & .0576 & .423 & \\
\hline
\end{tabular}

Figure (6): The main program interface for calculation the optimum lateral diameter

A rectangular plot area of $120 \mathrm{~m} \times 160 \mathrm{~m}$ was chosen a case study to test the model. The length of $120 \mathrm{~m}$ was assumed as the $\mathrm{x}$-axis of the area, while the length of $160 \mathrm{~m}$ was assumed as the y-axis of the area. At the $\mathrm{x}$-axis direction, the lateral lengths were $58 \mathrm{~m}$ at lateral diameters. The 
optimal inside diameter was $13.6 \mathrm{~mm}$ because it has the least annual cost which was 0.229 L.E/m/year. While the percent of pressure head variation with optimal diameter was $15.45 \%$, which is considered in the direction of $\mathrm{x}$-axis. Furthermore, at y-axis direction, the lateral lengths were $78 \mathrm{~m}$ at lateral diameters. The optimal inside diameter was $13.6 \mathrm{~mm}$ because it has the least annual cost per meter which was 0.239 L.E/m/year. While the percent of pressure head variation with optimal diameter was $19.62 \%$, which is considered in the direction of y-axis. On the other hand, the least value of pressure head variation was $12 \%$ at 36 $\mathrm{mm}$ lateral diameter at $\mathrm{x}$-axis direction, but the least value of pressure head variation was $12.04 \%$ at $36 \mathrm{~mm}$ lateral diameter at y-axis direction. Figure (7) shows a steep declare in total friction losses and percent of pressure head variation with the prime increase in lateral diameter (from $13.6 \mathrm{~mm}$ to $22 \mathrm{~mm}$ ), after reaching to diameter $28 \mathrm{~mm}$ the declinations in $\mathrm{H}_{\mathrm{f}}$ and $\mathrm{H}_{\text {var }}$ were very flat. The results of Figure (9) indicate that increasing internal diameter of the lateral makes approaching in the annual cost until $28 \mathrm{~mm}$, after that increase in the annual cost due to increase lateral diameter over $28 \mathrm{~mm}$ is less than before. The previous interpretations are similar to Figure (10) and (12).

The correlation between internal lateral diameters, total friction losses and percent of pressure head variation are shown in Figure (7) and (10) for the $\mathrm{X}$-axis and $\mathrm{y}$-axis respectively. The regression coefficient $\left(\mathrm{R}^{2}\right)$ values between lateral diameters and total friction losses were 1 at the two directions. Moreover the values of $\mathrm{R}^{2}$ between lateral diameters and percent of pressure head variation were approximately 0.895 and 0.903 for the $\mathrm{x}$-axis and y-axis respectively. On the other hand, in Figure (8) and (11), the values of $R^{2}$ between internal lateral diameters and the sum of repair plus energy annual costs per meter were 0.994 and 0.795 for the $\mathrm{x}$ axis and $y$-axis respectively. As well, the value of $\mathrm{R}^{2}$ was 0.989 between internal lateral diameters and annual fixed cost per meter for both axes. Also, in Figure (9) and (12), the values of $\mathrm{R}^{2}$ were 0.9906 and 0.9915 between internal lateral diameters and annual cost per meter for the $\mathrm{x}$-axis and $\mathrm{y}$-axis respectively.

The above results are very important when we get to choose the required diameter for the field. Increasing the diameter of laterals at the begin will 
bring out significant effect on the depended variable such as friction losses, pressure head variation and annual cost while increasing the diameter over $28 \mathrm{~mm}$ has a slight effect on the annual cost.

\section{Lateral in x-axis}

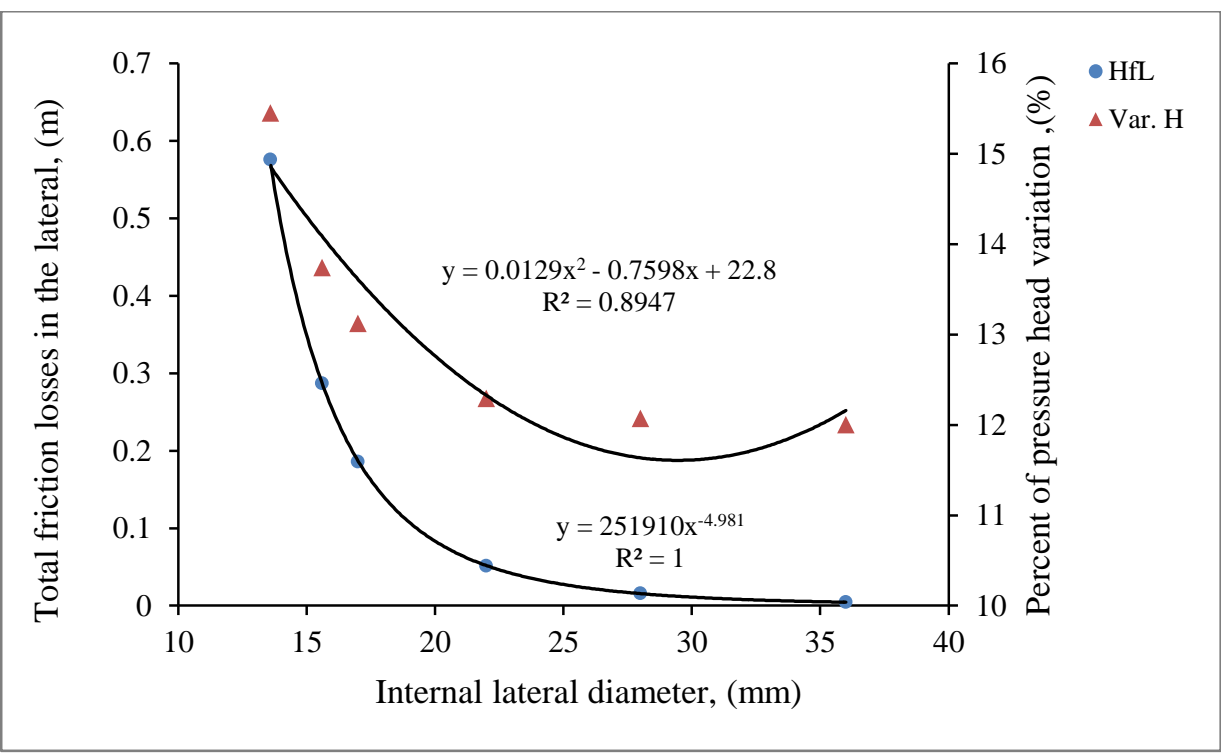

Figure (7): The correlation between internal lateral diameter, total friction losses and percent of pressure head variation at the $x$-axis.

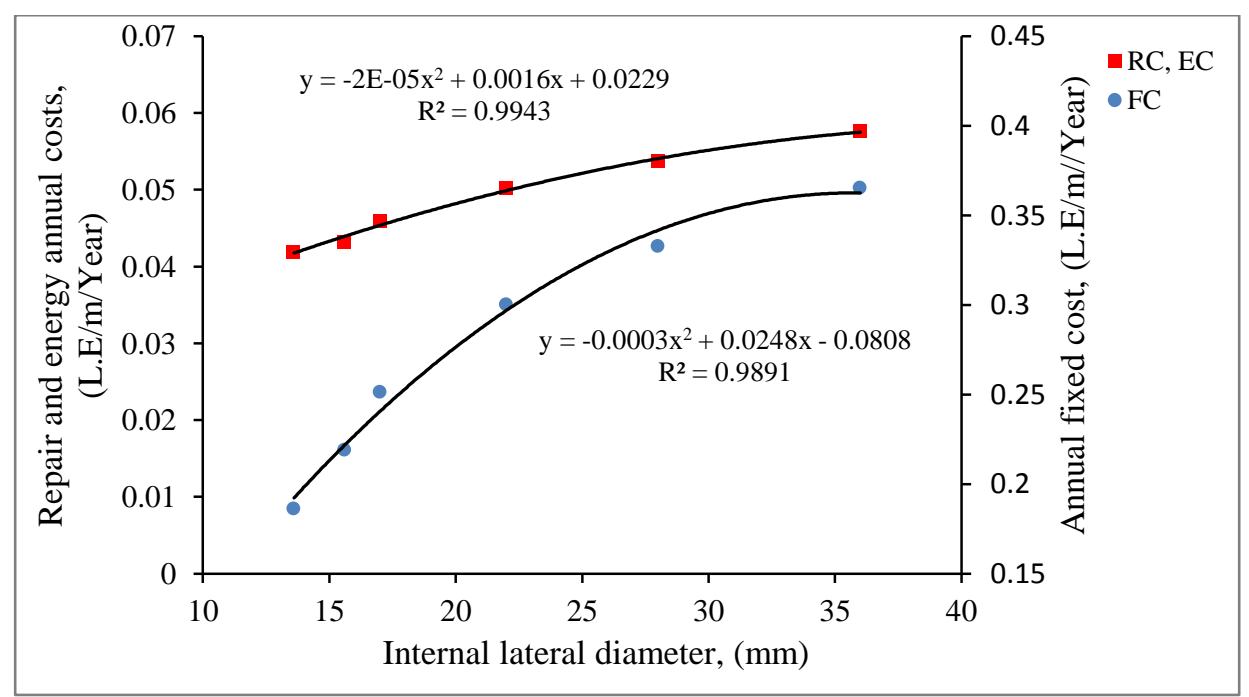

Figure (8): The correlation between internal lateral diameter, sum of repair plus energy annual costs per meter and annual fixed cost per meter at the $x$-axis. 


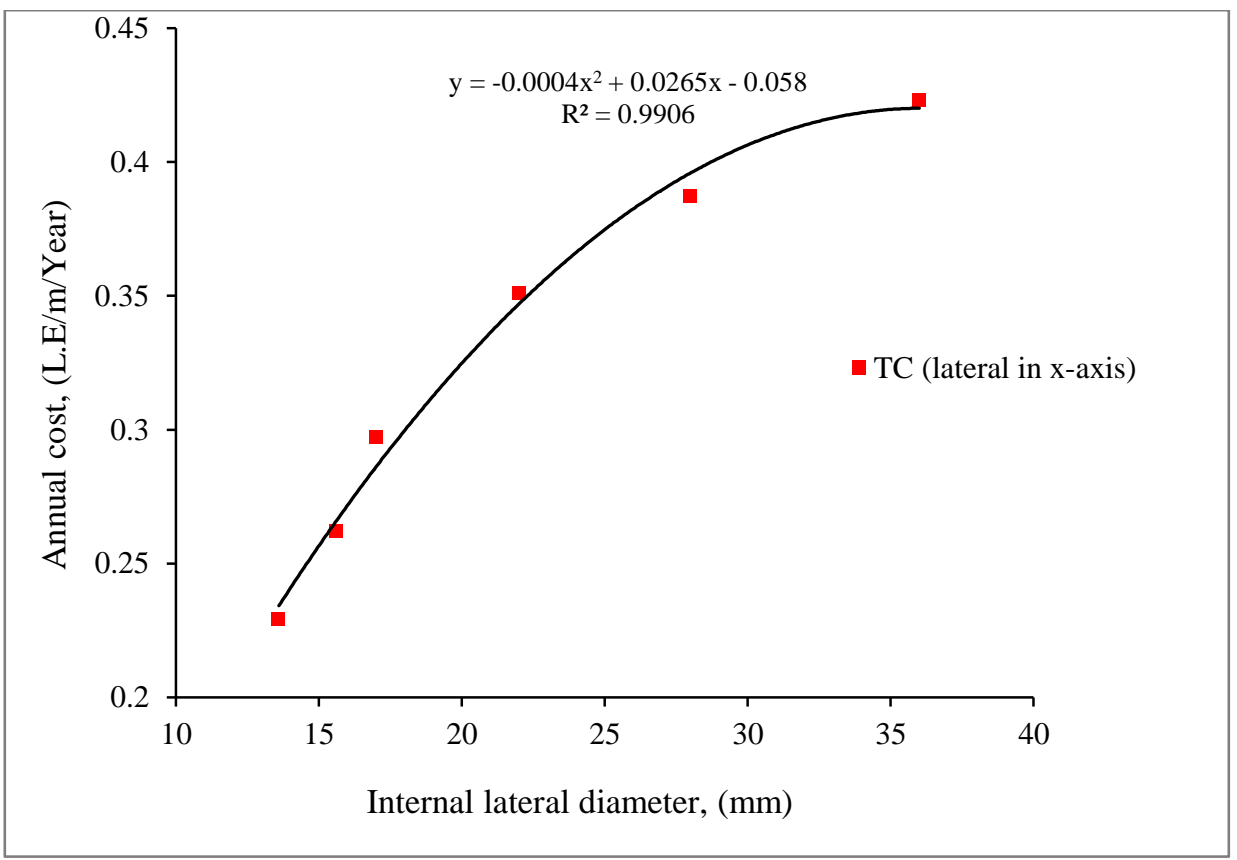

Figure (9): The correlation between internal lateral diameter and annual cost per meter at the $x$-axis.

\section{$\underline{\text { Lateral in y-axis }}$}

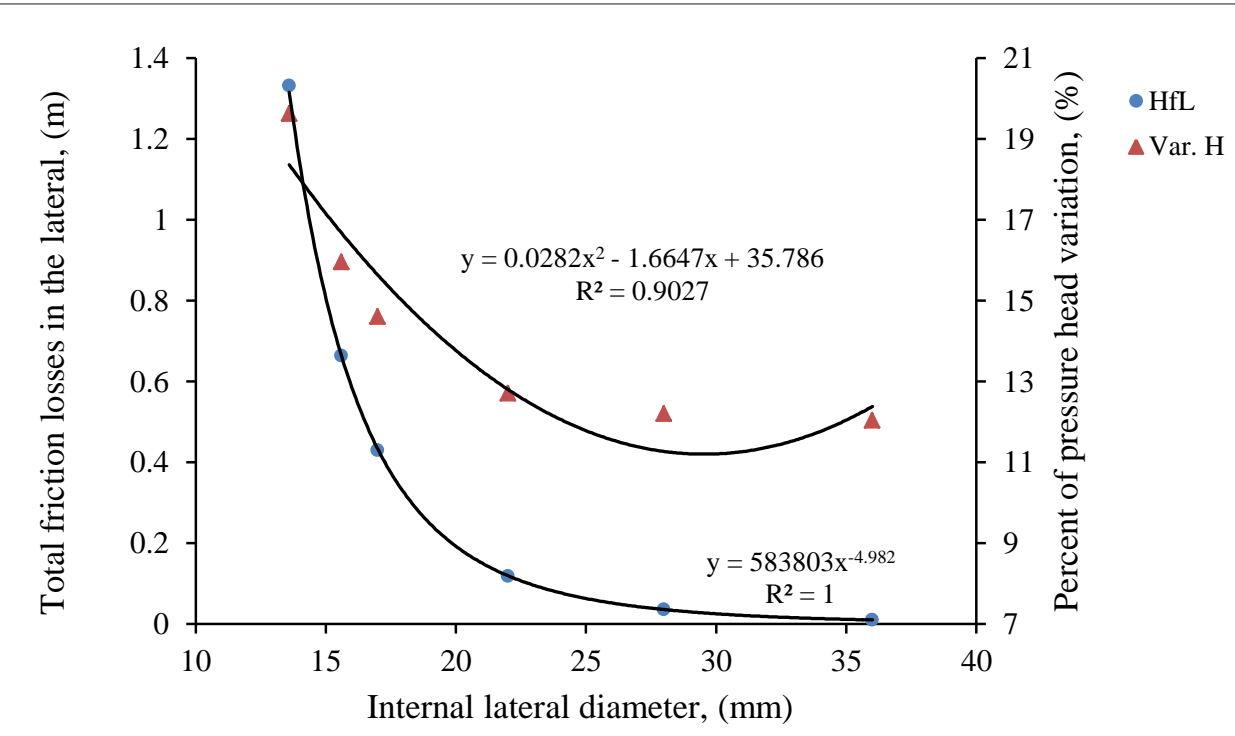

Figure (10): The correlation between internal lateral diameter, total friction losses and percent of pressure head variation at the $y$-axis. 


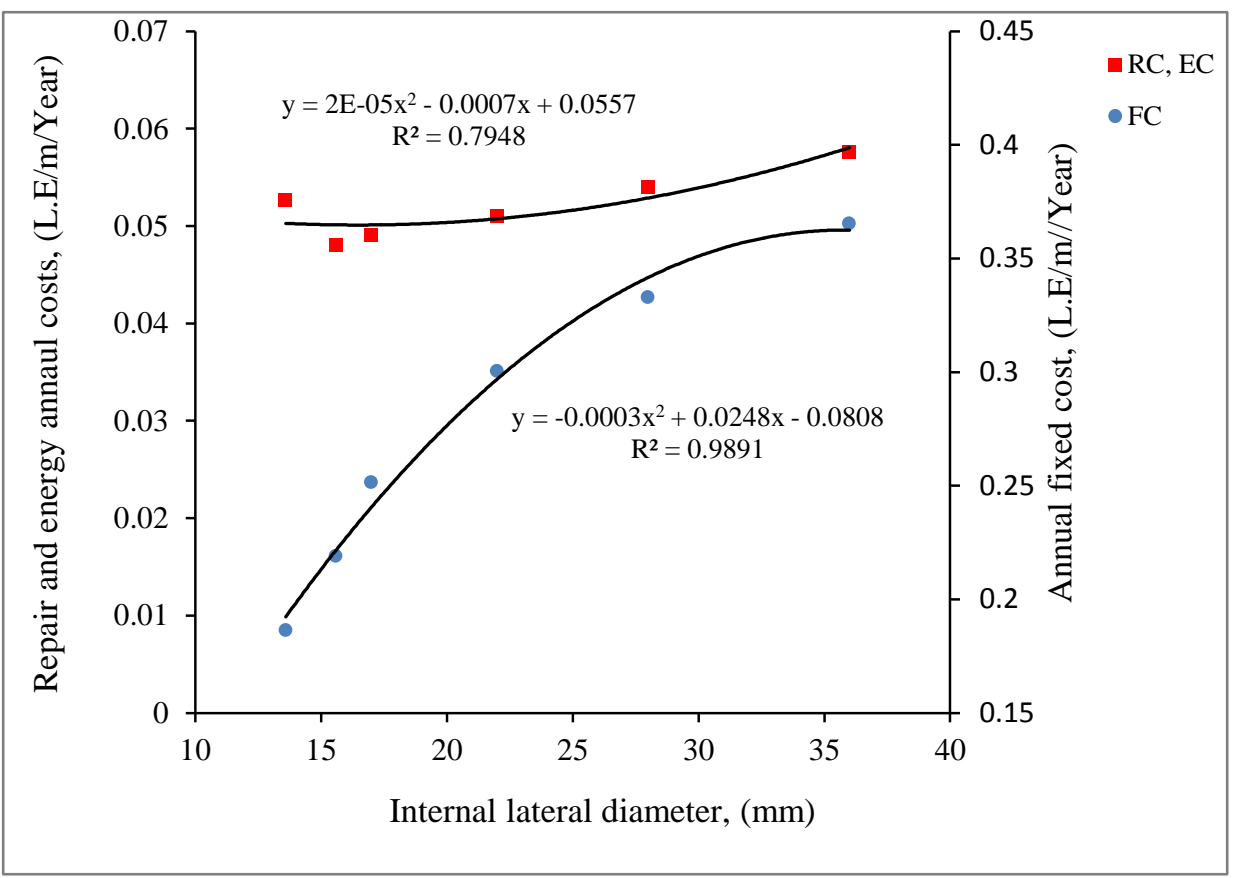

Figure (11): The correlation between internal lateral diameter, sum of repair plus energy annual costs per meter and annual fixed cost per meter at the y-axis.

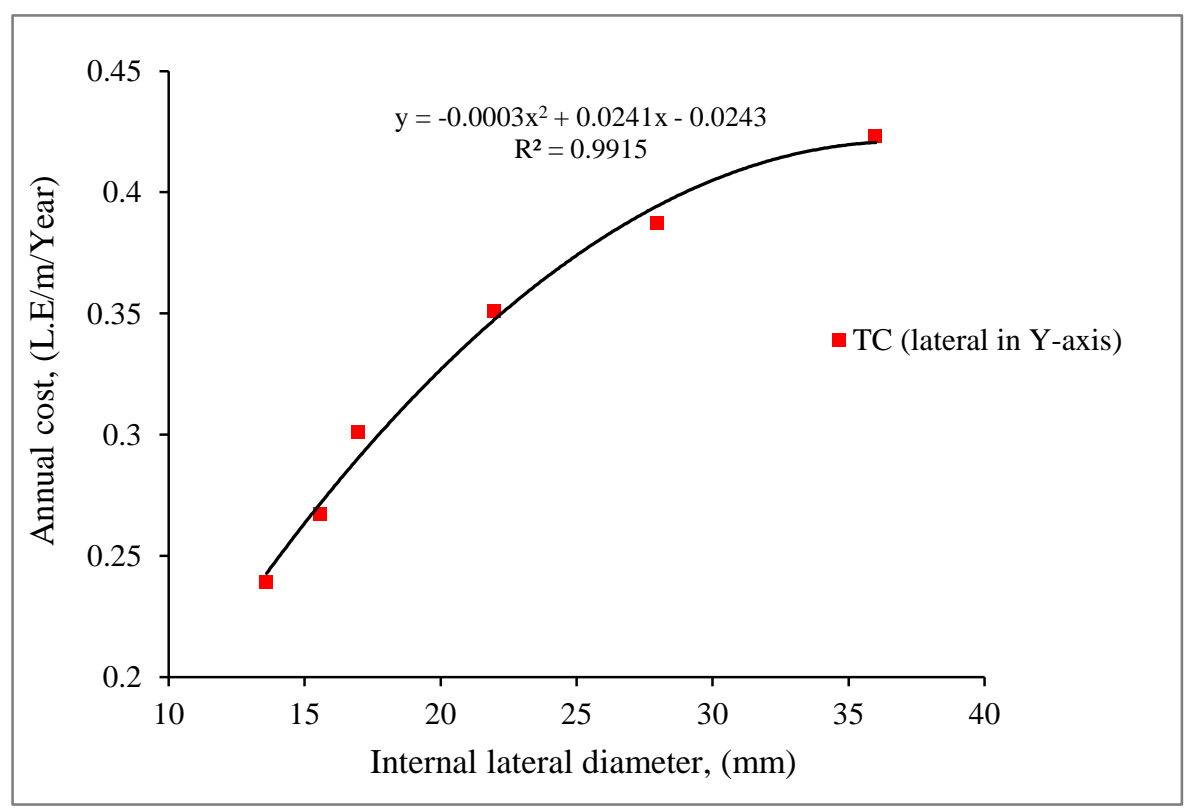

Figure (12): The correlation between internal lateral diameter and annual cost per meter at the y-axis. 


\section{CONCLUSIONS}

The present study aimed to create a computer model called OPT-LAT to calculate optimize design of micro-irrigation laterals. Validity of OPTLAT model was proved through comparison with Osama (2). The lateral lengths resulted from OPT-LAT model were close to the corresponding ones resulted by Osama (2).The regression coefficient values between predicted lateral lengths from OPT-LAT and lateral lengths from Osama (2) were 0.9996, 0.9991 and 0.9996 for lateral diameters 16, 18 and 20 $\mathrm{mm}$ respectively. This result proves the validity of OPT-LAT model in the calculation of lateral length for two directions. The OPT-LAT model is very good away for choosing the diameter of the lateral when the cost is taken in consider. From the management point of view, one can choose between lateral diameters without paying much and concern about the cost.

\section{REFERENCES}

Ahmed, O.M. 1997. A study on available alternative in planning of a trickle irrigation network. M.Sc. Thesis, Agricultural Mechanization Dept., Fac. Of Agric., Ain Shams Univ, PP134.

ASAE. 1990. Design and installation of micro-irrigation systems. ASAE EP405.1.

Boswell, M. J. 1985. Design characteristics of line-source drip tubes. Proceedings of the third International Drip/Trickle Irrigation Congress, Volume I, California, USA. pp. 306-312.

Burt, C. M.; A. J. Clemmens; T. S. Strelkoff; K. H. Solomon; R. D. Bliesner; L. A. Hardy; T. A. Howell and D. E. Eisenhaure. 1997. Irrigation performance measures: Efficiency and Uniformity. J. Irri. And Drain. Eng. Vol.123 No.6 pp. 423-442.

Christiansen, J. E. 1942. Irrigation by sprinkling. California Agric. Exp. Stn. Bull. 670. University of California, Berkeley. 
EL-Nesr, M. N. B. 1999. Computer aided design and planning of trickle irrigation systems. M.Sc. Thesis. Agr. Eng. Dept. Fac. Of Agric., Alex. Univ.,p 146.

Hezarjaribi, A.; A. A. Dehghani; H. M. Meftah and A. Kiani. 2008. Hydraulic performances of various trickle irrigation emitters. Journal of Agronomy, 7, 265-271.

James, L. D and R. R. Lee. 1971. Economics of water resources planning. McGraw Hill, Bombay and New Delhi, India.

Jensen, M. E. 1981. Design and operation of farm irrigation systems, An ASAE Monograph, American Society of Agricultural Engineers, St. Joseph, Mich.

Karmeli, D. and J. Keller. 1974. Trickle irrigation design. Rain Bird Sprinkler Manufacturing Crop. Glendora, Calif.

Karmeli, D. and J. Keller. 1975. Trickle Irrigation Design. Glendora, California: Rain Bird Sprinkler Manufacturing Corp.

Keller, J. and D. Karmeli. 1975. Trickle irrigation design. Glendora: Rain Bird Sprinkler Manufacturing.

Keller, J. and R. D. Bliesner. 1990. Sprinkle and trickle irrigation. Van Nostrand Reinhold, New York, ISBN: 0-442-24645-5.

Montalvo, T. 1983. A note on minor losses of emitter connections. Unpublished manuscript. Polytechnic Uni. Valencia, Spain. (C.F. Hanafy, M., 1990).

Pitts, D. J.; J.A. Ferguson and R.E. Wright. 1986. Trickle irrigation lateral line design by computer analysis. Trans. of the ASAE Vol 29(5): 1320-1324 
Ramadan, M.H.; H.N. Abdel-Mageed and M. Maher. 2003. Emitters performance in summer seasons of hot climate regions. International Scientific Conference, Agricultural Water Management and Mechanization Factors for Sustainable Agriculture, $8^{\text {th }}-10^{\text {th }}$ Oct., National Center for Agrarian Sciences. Institute for Land Reclamation and Agricultural Mechanization, Sofia, Bulgari. pp. 92-98.

Sharaf, G. A. 1996. Optimal design of trickle irrigation submain-unit. Misr J. Ag. Eng., 13 (3): pp. 501-515.

Soil Conservation Services (SCS). 1984. Trickle irrigation. U. S Dept. of Ag. National Engineering Handbook, Section 15, Chapter 7.

Solomon, K and J. C. Bezdek. 1980. Simulated flow rate requirements for some flushing emitters. ASAE and CSAE national meeting on trickle (drip) irrigation, paper no. 79-2571, Winnipeg, Canada.

Suliman, A. E.; M. M. El-Danasory; M. F. Hassan and M. H. AbdelWahed. 2004. Designing and evaluating drip irrigation unit by computer aid. Misr J. Ag . Eng., 21 (3):759 - 772

Thompson, G. T.; L. B. Spiess, and J. N. Krider. 1980. Farm Resources and System Selection. In Design and Operation of Farm Irrigation, Systems , M. E. Jensen (Ed.), ASAE Monograph 3, St. Joseph, MI, p. 45.

USDA. 2013. Microirrigation. Chapter 7, Part 623 (Irrigation) Natural resources conservation service. National Eng. Handbook.

Wu, I. P.; H. M. Gitlin; K. H. Solomon and C. A. Sarauwatari. 1986. Trickle irrigation for crop production, Design principles, Nakayama, F.S. and Bucks, D.A. (Ed.) Elsevier. 
Zazueta, F. S.; D. Gilpin-Hudson; A. G. Smajstrla and D. Z. Haman. 1985. Control +: a computer controller for irrigation systems. IFAS Ext. Cir. 688 (software). Univ. of Fla.

\section{الملخص العربي}

\section{التصميم الأقتصادى للخطوط الفرعية}

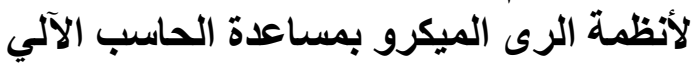

أ.د/ هثام ناجي عبد المجيد ' ، د/ محمد ماهر محمد إبراهيمَّ و م/ أسامة محمد الثربيني

تم اعداد برنامج (OPT-LAT) بغرض التصميم الأقتصادى للخطوط الفرعية لأنظمة الرى

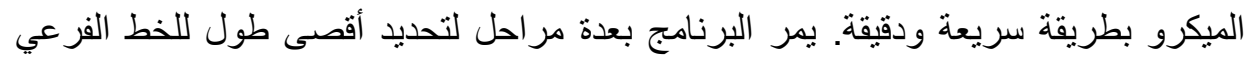

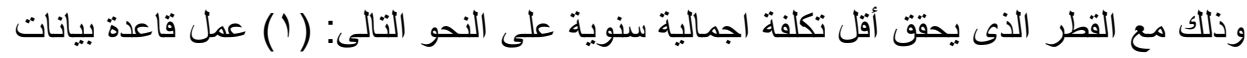

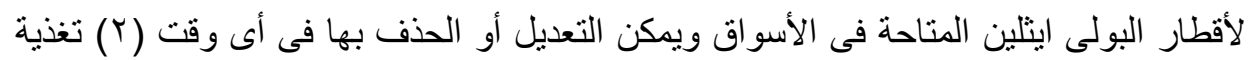

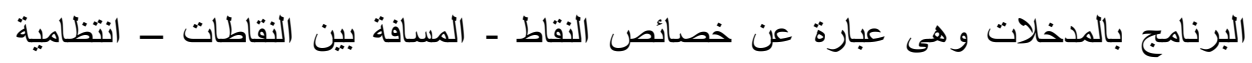

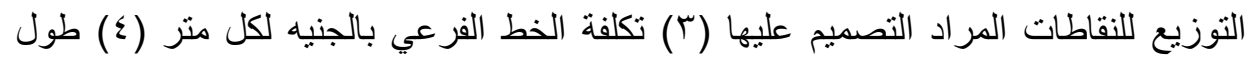

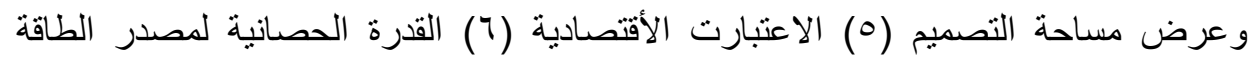

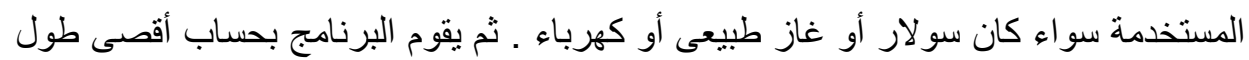

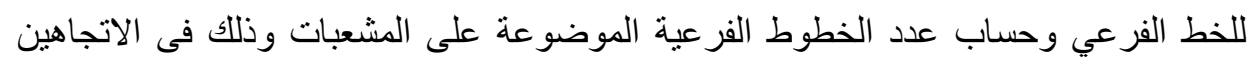

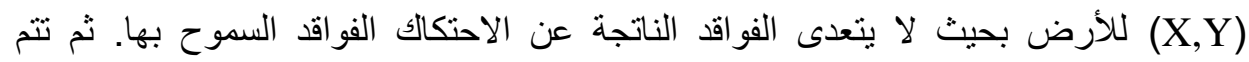

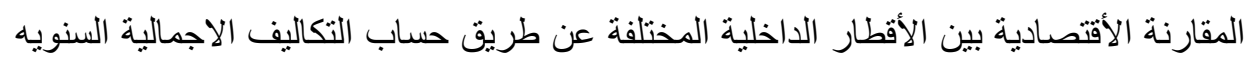

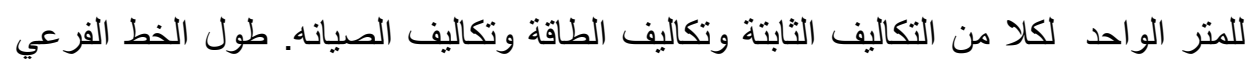
الأمثل عندئذ يكون عند القطر الداخلى الذى يحقق أقل تكاليف إجمالية سنوية للمتر الواحد.

إثبات صحة البرنامج:

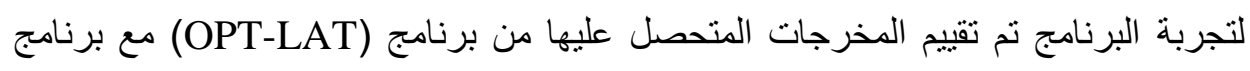

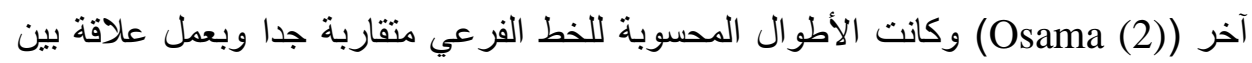

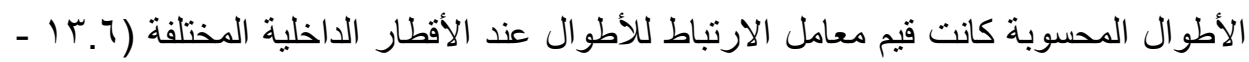

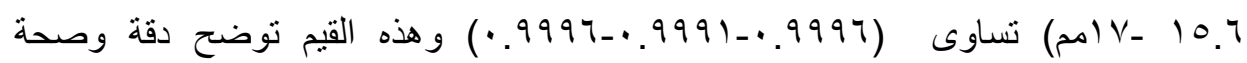
البرنامج فى حساب طول الخط الفرعي.

' أستاذ بقسم الهندسة الزراعية ـ كلية الزراعة ـ ـ جامعة المنصورة

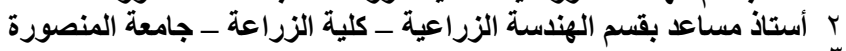

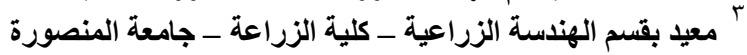


در اسة حالة:

تم عمل در اسة حالة للبرنامج لمساحة أرض ابعادها فى اتجاه (X) تساوى • Y ا مثر وفى اتجاه

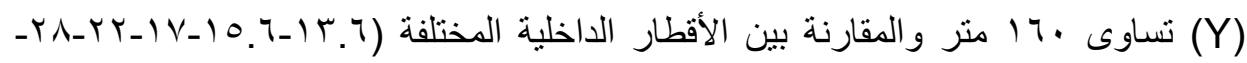
جسمم) وكانت البيانات المتحصل عليها من در اسة الحالة كالتالى:

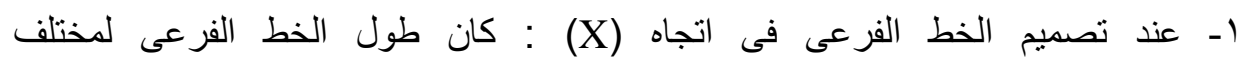

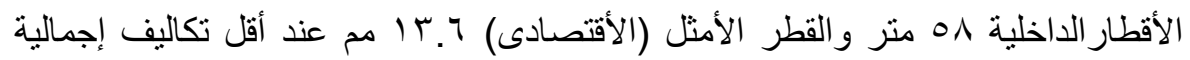

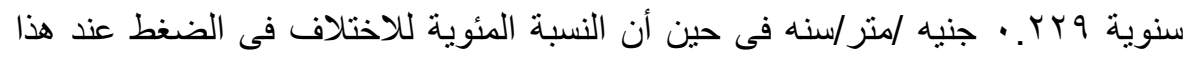

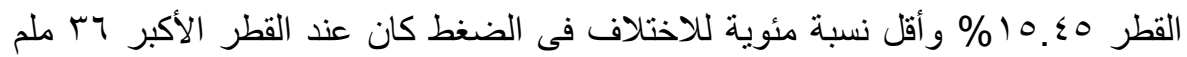
الذى يساوى Y I \%

Y- عند تصميم الخط الفرعى فى اتجاه (Y) : كان طول الخط الفرعى لمختلف

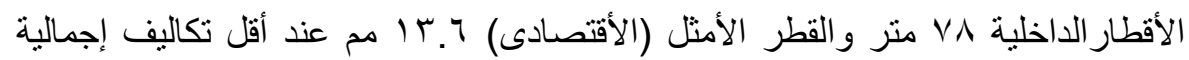

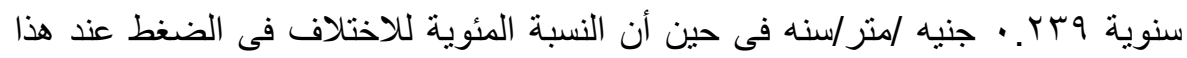

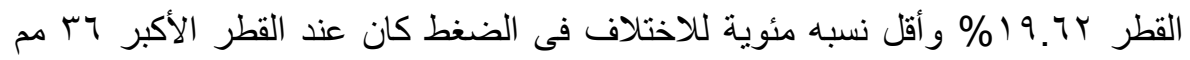

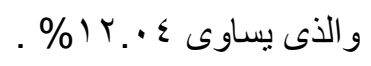

ب- أوضحت النتائج المتحصل عليها من النموذج الرياضي إنه كلما زاد قطر الخط الفرعي يقل الفواقد الناتجة عن الاحتكاك وتقل النسبة المئوية للاختلاف فى الضغط النه ويزداد النهاد التكاليف الإجمالية السنوية للطاقة والصيانة وكذلك يزداد التكاليف الإجمالية الثابتة السنوية ولكن بمعدلات مختلفة تتوقف على سعر الطاقة المستخدمة وسعر الخط الفرعى وتتم المقارنة بين هذين الأمرين واختيار الاتجاه الأفضل (الأقتصادى) وكذلك المفاضلة بولة بين اختيار القطر الأكبر أم اختيار القطر الاصغر أم التصميم فى اتجاه (X) أو (Y) ولاهن. 